\title{
Estimation of Changes in Content and Characteristics of Mold Flux during Continuous Casting
}

\author{
Shuhei IRIE $^{1)^{*}}$, Kenji Tsuzumi $^{1)}$, Akitoshi Matsui ${ }^{1)}$ and Naoki $\mathrm{KIKUCHI}^{1)}$ \\ 1) Steelmaking Research Department, Steel Research Laboratory, JFE Steel Corporation
}

Abstract: Estimation of changes in mold flux composition and physical properties during casting was investigated for control of slab surface quality. In this study, 0.7 mass $\% \mathrm{Al}$ steel and normal Al-killed steel were cast with three kinds of mold flux having $\mathrm{Al}_{2} \mathrm{O}_{3}$ contents of 1.3 to 6.0 mass $\%$ and different basicities. The results can be summarized as follows:

(1) The $\mathrm{Al}_{2} \mathrm{O}_{3}$ content of these mold fluxes increased to 30 mass $\%$ during continuous casting. The composition change of the mold flux can be reproduced by the Equilibrium Effective Reaction Zone Model (EERZM) by fitting parameters, referring to the casting results.

(2) The analysis by EERZM revealed that the viscosity of the mold flux and throughput of the molten steel affect the rate of increase of the $\mathrm{Al}_{2} \mathrm{O}_{3}$ content in the mold flux.

(3) The change of mold flux physical properties was estimated based on flux composition changes. The change of the crystallization temperature and main crystal can be estimated by FactSage.

(4) Mold flux viscosity can be estimated by revising the modified Iida's equation, which considers the effect of $\mathrm{Al}_{2} \mathrm{O}_{3}$ as an amphoteric oxide.

Keywords: continuous casting; high $\mathrm{Al}$ steel; mold flux; composition change; modelling; crystallization temperature; viscosity.

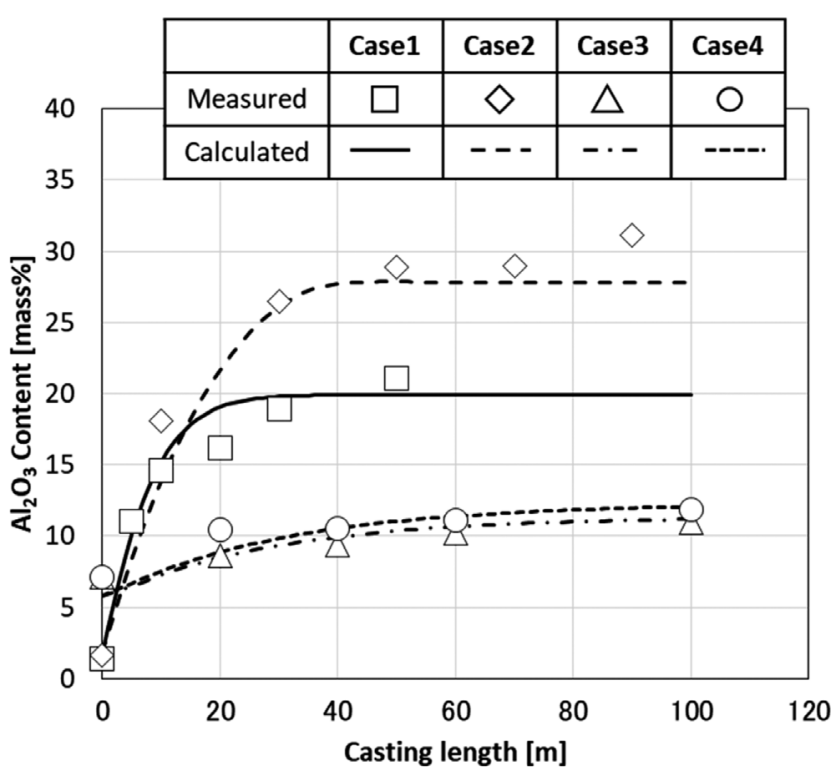




\title{
モールドフラックスの組成変動および特性変動の推算
}

\author{
入江 $\quad$ 脩平 ${ }^{1)} *$. 鼓 健二 ${ }^{1)}$ ・松井 章敏 ${ }^{1)}$ ・菊池 直樹 ${ }^{1)}$
}

Estimation of Changes in Content and Characteristics of Mold Flux during Continuous Casting

Shuhei Irie, Kenji Tsuzumi, Akitoshi Matsui and Naoki Kikuchi

\section{1. 緒言}

モールドフラックスは鋼の連続鋳造において重要な役割 を持っている。その役割とは, (1)溶鋼の保温 (2)溶鋼の再酸 化防止 (3)介在物の吸着 (4)凝固シェルの緩冷却化 (5)鋳型と 凝固シェルの潤滑性確保である ${ }^{1-3)}$ 。高品質な鋳片を生産 し, 安定的な生産を実現するためには, 溶鋼成分や, 鋳造 条件に応じて，上記役割を果たすことのできる最適なモー ルドフラックスを設計, 使用することが極めて重要であ る。通常, モールドフラックスは溶鋼成分, 鋳造条件を基 に適正な特性を設計し使用されているが，適正な特性をも つモールドフラックスであっても，操業上問題となること がある。例えば, 高 $\mathrm{Al}$, 高 $\mathrm{Mn}$, 高 $\mathrm{Ti}$ 鋼などの高合金鋼鋳造 時のモールドフラックスの組成変動 ${ }^{3-13)}$ がそれにあたる。

高合金鋼鋳造時のモールドフラックスの組成変動は, 溶 鋼 - モールドフラックス間の酸化還元反応が原因で起こ る ${ }^{3-9)}$ と報告されている。一般に，モールドフラックスに は，一定量の $\mathrm{SiO}_{2}$ が含まれている。高合金鋼に含まれる $\mathrm{Al}, \mathrm{Mn}, \mathrm{Ti}$ な゙の元素がモールドフラックス中の $\mathrm{SiO}_{2}$ を還 元してしまい，自身も酸化されることで，モールドフラッ クスの組成が著しく変化させる。その結果，モールドフ ラックスの特性が鋳造中に大きく変化し，鋳造が不安定に なり，トラブルや鋳造性欠陥などを引き起こす ${ }^{3-6,9)}$ 。っ て, 高合金鋼 (高 $\mathrm{Al}, \mathrm{Mn}, \mathrm{Ti}$ 鋼) の品質向上および鋳造安 定性向上のためには，鋳造中のモールドフラックスの組成 変動を把握することが重要となる。

高合金鋼 (高 $\mathrm{Al}$, 高 $\mathrm{Mn}$, 高 $\mathrm{Ti}$ 鋼) における鋳造不安定化 のメカニズムを高 $\mathrm{Al}$ 含有鋼の場合を例に説明する。高 $\mathrm{Al}$ 含有鋼鋳造中は, 溶鋼 - モールドフラックス間の Si-Alの酸 化還元反応 (式 (1)) が進む。

$$
\begin{aligned}
& 4 \mathrm{Al}_{\text {in molten steel }}+3 \mathrm{SiO}_{2 \text { in mold flux }} \\
& \rightarrow 3 \mathrm{Si}_{\text {in molten steel }}+2 \mathrm{Al}_{2} \mathrm{O}_{3 \text { in mold flux }}
\end{aligned}
$$

この反応により, モールドフラックス中の $\mathrm{SiO}_{2}$ 濃度が大 きく低下, $\mathrm{Al}_{2} \mathrm{O}_{3}$ 濃度が大きく上昇し，モールドフラックス
の組成扎よび塩基度が大きく変化する。高 $\mathrm{Al}$ 含有鋼の鋳 造中にはモールドフラックス内の $\mathrm{Al}_{2} \mathrm{O}_{3}$ 濃度が 5 mass $\%$ 以 下から最大約 35 mass \%まで上昇し, $\mathrm{SiO}_{2}$ 濃度は $40 \mathrm{mass} \%$ 以上から約 20 mass $\%$ まで低下すると報告されている ${ }^{3-6)}$ 。 $\mathrm{SiO}_{2}$ はモールドフラックスの主成分であり，かつ，モール ドフラックスの特性に大きく影響を与える溶融酸化物内の ネットワークへの重要な因子であるため, 鋳造安定性にお いて重要な特性である結晶化温度や粘度などが大きく変化 し, 凝固シェル - 鋳型間へのモールドフラックスの流入が 不均一になり, 大きなディプレッションを生成する。その 結果，割れや重大なトラブルであるブレイクアウト (BO) を引き起こすことになる ${ }^{3-6,9)}$ 。

本報では，高合金鋼における鋳造不安定化を防止するこ とを目的に，テスト鋳造およびモールドフラックスの特性 測定を実施し，モールドフラックスの組成変動により起こ る特性変動を予測する手段として，

・鋳造中のモールドフラックスの組成変動を推算するモデ ル

・組成変動による結晶化温度の変化を推算するモデル

・組成変動による粘度の変化を推算するモデル

を検討し，これらの妥当性を検証した。今回は，モール ドフラックスの組成, 特性が特に大きく変化する高 $\mathrm{Al}$ 含有 鋼鋳造時のモールドフラックスを対象とした。

\section{2. 実験方法および計算方法}

\section{$2 \cdot 1$ 組成変動予測モデル}

溶鋼 - モールドフラックス間の Si-Al 酸化還元反応による モールドフラックスの組成変動を予測するモデルを検討し た。高 $\mathrm{A} 1$ 含有鋼鋳造時のモールドフラックスの組成変動を 予測するモデルは種々提案されている ${ }^{14-16)}$ 。今回は, 熱力 学計算 (FactSage) と混合モデル (ERZM: Effective Reaction Zone Model）を組み合わせたモデル（EERZM: Equilibrium Effective Reaction Zone Model ${ }^{17)}$ を採用した。このモデル は, Van Ende and Jung が高合金鋼鋳造中のモールドフラッ 
クスの組成変動を再現するために提案した熱力学計算 (FactSage) と混合モデル (ERZM) を組み合わせたモデル (EERZM) である ${ }^{17)}$

FactSage は多成分系 (多元系) の熱力学的平衡状態を計 算するソフトェアである。酸化物系の平衡状態図や合金状 態図の計算, 電位 -pH 図の作成, 溶融スラグ・ガラスの粘 度の予測, 熱力学データベースの作成等の機能を持ってい る。

混合モデル（ERZM）は，反応速度，物質移動をゾーン

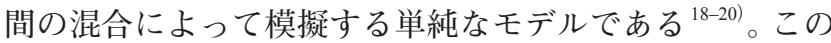
モデルでは，2つの相の界面付近の反応領域を複数のゾー ンに分割し，各ゾーン間の平衡反応を計算し，その後，混 合することで反応速度および物質移動を模擬する。このと き，各ゾーンの厚み (体積) を変更することで，界面反応の 反応速度扎よび各相内の物質移動の程度を模擬しており, 平衡反応のみ考慮しているモデルではあるが，反応速度， 物質移動を考慮した組成変動を再現することができる。

今回用いたモールドフラックス組成変動予測モデルの 模式図を Fig.1に示す ${ }^{17)}$ 。このモデルでは, 溶融モールドフ ラックスをSlag layer1, Slag layer2, Slag layer3に3 分割し, 溶鋼を Steel layerの1層としている。これらの厚みを変更す ることで，上述したように，溶鋼 - モールドフラックス間 の反応の反応速度，モールドフラックス内の物質移動を模 擬している。つまり，これらの各層の厚みが本モデルのパ ラメータである。

モデル上の仮定を以下に示す。

・溶鋼層（Steel layer）と溶鋼層に接しているモールドフ ラックス層（Slag layer1）の温度は同じである。

・系に投入されるモールドフラックスは全て溶融した状態 で系内に流入する。

・モールドフラックスの系外への流出はモールドフラック ス消費量と同じで, 各layer厚みに応じて, 各layerから流 出する。
・各 Slag layer およびSteel layerのサイズはモールドの厚 み，幅と同じとする。

・鋳造中の各Slag layer, Steel layerの厚みは一定であると する。

・平衡反応の計算には固相，液相共に考慮する。

・モデル上の Slag layer全体の厚みは, 鋳造時の溶融モール ドフラックス層の厚みと同じとする。

計算手順を簡単に説明する。まず，溶鋼と溶鋼に近接す るモールドフラックス層間 (Steel layer-Slag layer1 間) の平 衡反応を計算する。次に, Slag layer1 から Slag layer3の物質 の流出入を順に計算する。この時に各layerの流出量はモー ルドフラックス消費量に溶融モールドフラックス層全体の 厚みに対する各layerの厚みの比率をかけた量とし，流入に ついては上方の layerから各layerの流出量と同量を流入さ せる。Slag layer3については使用しているモールドフラッ クスをモールドフラックス消費量と同量分流入させる。最 後に，隣り合うslag layer同士で各layerの50\%ずつを混合 させる。この時のモールドフラックス全体の平均組成を 結果として出力する。これらの手順を 1 stepとして繰り返 し計算を行なう。今回は 1 stepを 1 min とした。計算条件を Table 1 に示す。各layerでそれぞれ温度は一定とし，介在物 は全て $\mathrm{Al}_{2} \mathrm{O}_{3}$ と仮定し，一定量が溶鋼からモールドフラッ クスに流入するとした。

検証対象としたテスト鋳造の鋳造条件を Table 2 に示す。 今回対象にしたのは，中炭-0.7 mass\%Al鋼および極低炭， 低炭 $\mathrm{Al}$ キルド鋼である。モールドフラックスは塩基度や

Table 1. Calculation condition.

\begin{tabular}{c|c|c}
\hline \multirow{4}{*}{ Temperature of layer } & $\begin{array}{c}\text { Steel layer } \\
\text { Slag layer1 }\end{array}$ & $1550^{\circ} \mathrm{C}$ \\
\cline { 2 - 3 } & Slag layer2 & $1500^{\circ} \mathrm{C}$ \\
\cline { 2 - 3 } & Slag layer3 & $1450^{\circ} \mathrm{C}$ \\
\hline \multirow{2}{*}{ Inclusion } & Concentration of $\mathrm{Al}_{2} \mathrm{O}_{3}$ & $20 \mathrm{ppm}$ \\
\cline { 2 - 3 } & Removal rate & $15 \%$ \\
\hline
\end{tabular}

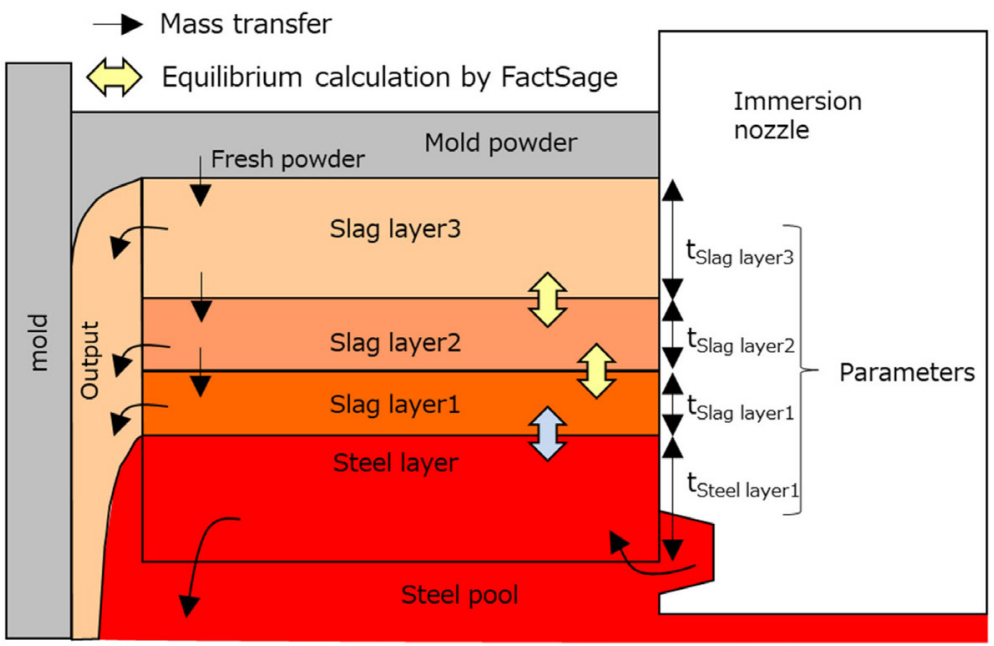

Fig. 1. Schematic of Equilibrium Effective Reactions Zone Model in mold flux. (Online version in color.) 
特性が異なる3 種類のFlux A, Flux B, Flux Eを用いた。ま た，各Case でスループット指数 $\mathrm{I}_{\mathrm{TP}}$ が異なる条件とした。ス ループット指数 $\mathrm{I}_{\mathrm{TP}}$ は, 各Caseのモールドフラックス流量 に対する溶鋼流量 $\mathrm{R}_{\text {Steel-Mold flux }}$ を Case1 の場合を 1 として指 数化したものである。モールドフラックス流量に対する溶 鋼流量 $\mathrm{R}_{\text {Steel-Mold flux }}$ は式 (2) で表される。

$$
R_{\text {Steel-Mold flux }}=\frac{Q_{\text {Steel }}}{Q_{\text {Mold flux }}}=\frac{\rho \times V_{c} \times t_{\text {slab }} \times w_{\text {slab }}}{C_{\text {Mold flux }} \times V_{c} \times 2 \times\left(t_{\text {slab }}+w_{\text {slab }}\right)}
$$

$\mathrm{R}_{\text {Steel-Mold flux }}[\mathrm{t} / \mathrm{kg}]$ : モールドフラックス流量に対する溶 鋼流量, $\mathrm{Q}_{\text {Steel }}[\mathrm{t} / \mathrm{min}]$ : 溶鋼流量 (=スループット), $\mathrm{Q}_{\text {Mold flux }}$ $[\mathrm{kg} / \mathrm{min}]$ : モールドフラックス流量, $\rho\left[\mathrm{t} / \mathrm{m}^{3}\right]$ : 溶鋼の密度, $\mathrm{V}_{\mathrm{c}}[\mathrm{m} / \mathrm{min}]$ : 鋳造速度, $\mathrm{t}_{\mathrm{slab}}[\mathrm{m}]$ : 鋳片厚み, $\mathrm{w}_{\text {slab }}[\mathrm{m}]$ : 鋳片幅, $\mathrm{C}_{\text {Mold flux }}\left[\mathrm{kg} / \mathrm{m}^{2}\right]$ : モールドフラックス消費量

これらの条件で行なったテスト鋳造の $\mathrm{Al}_{2} \mathrm{O}_{3}$ 濃度変化 の実績に対して，モデルパラメータである各層厚み $\left(\mathrm{t}_{\text {Slag }}\right.$ layer1 $\left., \mathrm{t}_{\text {Slag layer2 }}, \mathrm{t}_{\text {Slag layer3 }}, \mathrm{t}_{\text {Steel layer }}\right)$ を種々変更し計算を行ない, チューニングを行なった。

\section{$2 \cdot 2$ 特性推算モデル}

鋳造の安定性に大きな影響を与えるモールドフラックス の特性, 結晶化温度と粘度について推算する手法を検討し た。

検討のために用いたモールドフラックスの組成, 特性 を Table 3 に示す。塩基度の異なる Flux B〜D およびそれぞ れのモールドフラックスにおいて $\mathrm{Al}_{2} \mathrm{O}_{3}$ 濃度の上昇を模擬 したモールドフラックスを対象とした。各特性の推算には FactSageを用いた。結晶化温度は固相が存在する最高温度 とし, 主結晶種は結晶化温度で存在する固相とした。粘度 はFactSageのViscosity モジュールを用いて各組成の 1573 K におけるスラグの粘度を算出した。モールドフラックスの 各特性の測定は以下のように行なった。主結晶種は溶融し たモールドフラックスを水冷銅板で急冷し得られたサンプ ルを粉末 X線回折測定法 (粉末 XRD) にて同定した。結晶

Table 2. Casting conditions.

\begin{tabular}{|c|c|c|c|c|c|}
\hline & & Case 1 & Case2 & Case3 & Case4 \\
\hline \multirow{2}{*}{ Steel composition [mass $\%]$} & $\mathrm{C}$ & \multicolumn{2}{|c|}{0.17} & 0.002 & 0.02 \\
\hline & $\mathrm{Al}$ & \multicolumn{2}{|c|}{0.7} & 0.04 & 0.02 \\
\hline \multicolumn{2}{|l|}{ Mold flux } & Flux A & Flux B & \multicolumn{2}{|c|}{ Flux E } \\
\hline \multicolumn{2}{|l|}{ Original composition of $\mathrm{Al}_{2} \mathrm{O}_{3}[\mathrm{mass} \%]$} & 1.3 & 1.6 & \multicolumn{2}{|c|}{6.0} \\
\hline \multicolumn{2}{|l|}{ Basicity T.CaO/SiO ${ }_{2}[-]$} & 0.6 & 1.2 & \multicolumn{2}{|c|}{0.7} \\
\hline \multicolumn{2}{|l|}{ Viscosity at $1573 \mathrm{~K}$ [poise] } & 1.7 & 0.9 & \multicolumn{2}{|c|}{4.0} \\
\hline \multicolumn{2}{|l|}{ Crystallization Temperature $\left[{ }^{\circ} \mathrm{C}\right]$} & 860 & 1130 & \multicolumn{2}{|c|}{960} \\
\hline \multicolumn{2}{|l|}{ Casting machine } & \multicolumn{2}{|c|}{$\mathrm{X}$} & \multicolumn{2}{|c|}{$\mathrm{Y}$} \\
\hline \multicolumn{2}{|l|}{ Casting velocity $\mathrm{V}_{\mathrm{c}}[\mathrm{m} / \mathrm{min}]$} & 1.0 & 0.8 & 1.8 & 1.6 \\
\hline \multicolumn{2}{|l|}{ Slab thickness $\mathrm{t}_{\text {slab }}[\mathrm{mm}]$} & \multicolumn{2}{|c|}{235} & \multicolumn{2}{|c|}{260} \\
\hline \multicolumn{2}{|l|}{ Slab width $\mathrm{W}_{\text {slab }}[\mathrm{mm}]$} & \multicolumn{2}{|c|}{1450} & 1500 & 1615 \\
\hline \multicolumn{2}{|l|}{$\mathrm{I}_{\mathrm{TP}}[-]$} & 1.0 & 0.81 & 1.60 & 1.79 \\
\hline
\end{tabular}

化温度は示差走査熱量計 (DSC) を用いて, $1300^{\circ} \mathrm{C}$ か $4^{\circ} \mathrm{C}$ $/ \min$ の冷却条件で測定した。粘度は回転粘度計を用いて, 1573 Kで測定した。

\section{3. 実験結果および計算結果}

\section{$3 \cdot 1$ 組成変動予測モデル}

テスト鋳造におけるモールドフラックス中の $\mathrm{Al}_{2} \mathrm{O}_{3}$ 濃度 変化の実績をFig.2に示す。溶鋼中の Al濃度が高いCase1 およびCase2ではモールドフラックス中の $\mathrm{Al}_{2} \mathrm{O}_{3}$ 濃度が鋳 造中に大きく変化した。また, 塩基度の高いFlux Bを用い ているCase2において，モールドフラックス中の $\mathrm{Al}_{2} \mathrm{O}_{3}$ 濃度 が最も高くなり, $\mathrm{Al}_{2} \mathrm{O}_{3}$ 濃度が約 30 mass \%まで上昇した。 一方，溶鋼中の $\mathrm{Al}$ 濃度が低いCase3 およびCase4において もモールドフラックス中の $\mathrm{Al}_{2} \mathrm{O}_{3}$ 濃度は約 $5 \mathrm{mass} \%$ 程度上 昇した。

Fig.2の $\mathrm{Al}_{2} \mathrm{O}_{3}$ 濃度変化の実績に対して, モデルパラメー タをチューニングした結果を Fig.3に示す。全Caseにおい て，特定のパラメータに設定することで，テスト鋳造時の

Table 3. Compositions and measured characteristics of mold fluxes.

\begin{tabular}{c|c|c|c|c}
\hline & $\begin{array}{c}\text { Composition } \\
{[\text { mass\%] }}\end{array}$ & $\begin{array}{c}\mathrm{T} . \mathrm{CaO} / \mathrm{SiO}_{2} \\
{[-]}\end{array}$ & $\begin{array}{c}\text { Viscosity } \\
\text { [poise] }\end{array}$ & $\begin{array}{c}\text { Crystallization } \\
\text { temperature } \\
{\left[{ }^{\circ} \mathrm{C}\right]}\end{array}$ \\
\cline { 2 - 5 } $\mathrm{Al} \mathrm{O}_{3}$ & 1.6 & 1.2 & 0.9 & 1130 \\
\hline $\mathrm{B}-10$ & 11.3 & 1.49 & 1.3 & 1000 \\
\hline $\mathrm{B}-20$ & 20.7 & 2.12 & 1.8 & 1130 \\
\hline $\mathrm{B}-30$ & 29.5 & 3.45 & 2.7 & 1160 \\
\hline $\mathrm{C}$ & 1.6 & 1.4 & 0.7 & 1145 \\
\hline $\mathrm{C}-10$ & 11.3 & 1.78 & 0.9 & 1020 \\
\hline $\mathrm{C}-20$ & 20.7 & 2.72 & 1.2 & 1150 \\
\hline $\mathrm{C}-25$ & 25.1 & 3.54 & 1.7 & 1200 \\
\hline $\mathrm{C}-30$ & 29.5 & 5.13 & 2.3 & 1245 \\
\hline $\mathrm{D}$ & 9.5 & 1.81 & 0.8 & 1030 \\
\hline $\mathrm{D}-10$ & 19.3 & 2.78 & 1.0 & 1150 \\
\hline $\mathrm{D}-15$ & 24.1 & 3.78 & 1.1 & 1165 \\
\hline $\mathrm{D}-22$ & 31.3 & 7.77 & 1.1 & 1200 \\
\hline $\mathrm{D}-27$ & 34.5 & 7.79 & 1.5 & 1255 \\
\hline
\end{tabular}

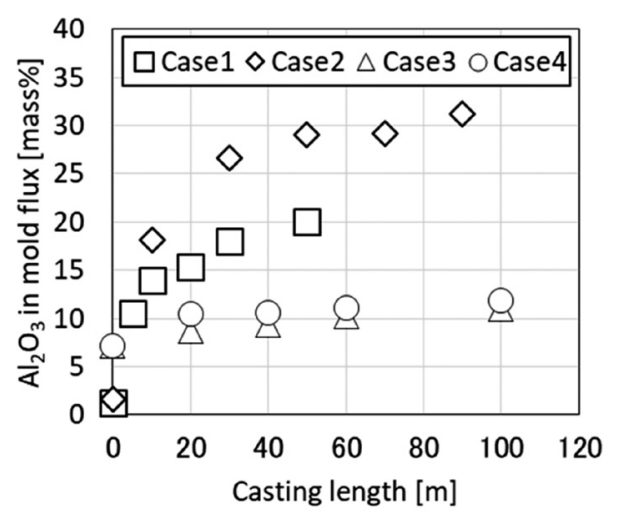

Fig. 2. Change in $\mathrm{Al}_{2} \mathrm{O}_{3}$ content in mold flux during test casting. 
$\mathrm{Al}_{2} \mathrm{O}_{3}$ 濃度変化の実績を再現できた。各Caseにおいて $\mathrm{Al}_{2} \mathrm{O}_{3}$ 濃度変化の実績を再現できたモデルパラメータを Table 4 に示す。ここで，モデルパラメータ $\mathrm{r}_{\text {Steel layer, }}, \mathrm{r}_{\text {Slag layer } 1}, \mathrm{r}_{\text {Slag }}$ ${ }_{\text {layer2 }}, \mathrm{r}_{\text {Slag layer3 }}$ は, 溶融モールドフラックス層全体の厚み $\mathrm{t}_{\mathrm{Total}}$ slag layer に対する各layerの厚みの比率である (式 (3), 式 (4))。

$r_{i}=\frac{t_{i}}{t_{\text {total slaglayer }}}$

$i=$ Steel layer, Slag layer1, Slag layer 2, Slag layer3

$t_{\text {Total slag layer }}=t_{\text {Slag layer } 1}+t_{\text {Slag layer } 2}+t_{\text {Slag layer } 3}$

$r_{i}[-]$ : モールドフラックス層全体の厚みに対する各layer の厚みの比, $\mathrm{t}_{\mathrm{i}}[\mathrm{mm}]$ : 各 layerの厚み, $\mathrm{t}_{\text {Total layer }}[\mathrm{mm}]$ : モール ドフラックス層全体の厚み

Table 4 に示したように, 各Caseにおけるモデルパラメー タは異なっていた。各Case間でのモデルパラメータの違い は，モールドフラックスの特性およびスループットの違い によるものだと考えられる。モールドフラックスの初期組 成の粘度と $\mathrm{r}_{\text {Slag layer1 }}$ の関係扎よび，スループット指数 $\mathrm{I}_{\mathrm{TP}}$ と $\mathrm{r}_{\text {Steel layer }}$ の関係を Fig.4に示す。モールドフラックスの初期組 成の粘度が高いほど, Slag layer1の厚みが小さくなり，ス

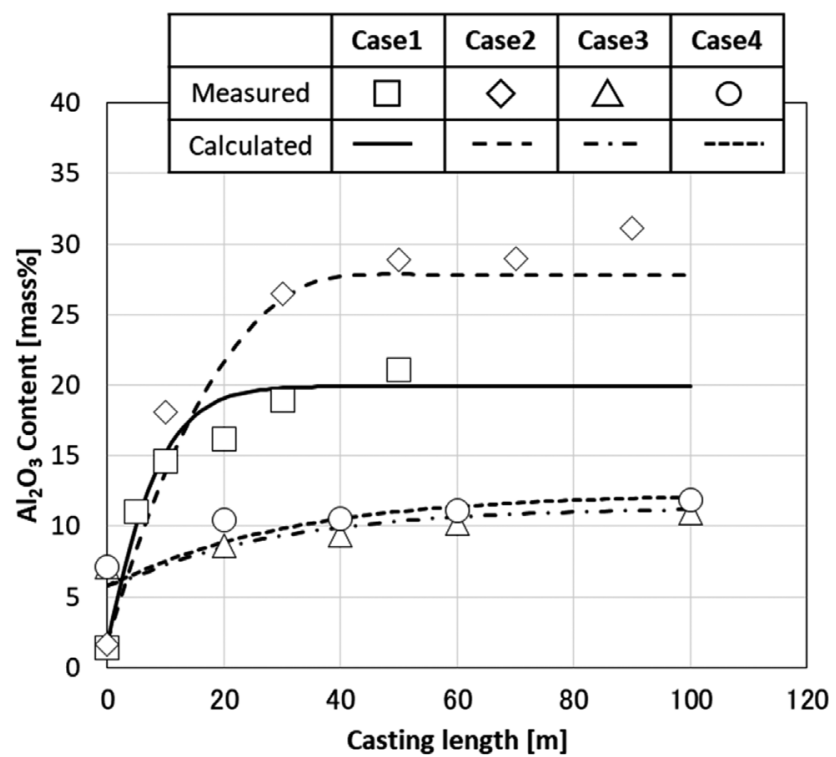

Fig. 3. Change of measured and calculated $\mathrm{Al}_{2} \mathrm{O}_{3}$ content in mold flux during test casting.

Table 4. Casting condition and model parameters.

\begin{tabular}{c|c|c|c|c}
\hline & Case1 & Case2 & Case3 & Case4 \\
\hline Flux & Flux A & Flux B & \multicolumn{2}{|c}{ Flux E } \\
\hline Viscosity [poise] & 1.7 & 0.9 & \multicolumn{2}{|c}{4.0} \\
\hline $\mathrm{I}_{\mathrm{TP}}[-]$ & 1.0 & 0.81 & 1.60 & 1.79 \\
\hline $\mathrm{r}_{\text {Slag layer3 }}[-]$ & 0.5 & 0.3 & 0.53 & 0.53 \\
\hline $\mathrm{r}_{\text {Slag layer2 }}[-]$ & 0.3 & 0.1 & 0.43 & 0.43 \\
\hline $\mathrm{r}_{\text {Slag layer1 } 1-]}[-]$ & 0.2 & 0.6 & 0.03 & 0.03 \\
\hline $\mathrm{r}_{\text {Steel layer }}[-]$ & 0.5 & 0.4 & 1.5 & 2.5 \\
\hline
\end{tabular}

ループット指数が大きいほど, Steel layerの厚みが大きく なっていることが分かる。

\section{$3 \cdot 2$ 特性推算モデル}

FactSage を用いた主結晶種，結晶化温度の推算結果をそ れぞれ Table 5, Fig.5, Fig.6に示す。FactSageによる主結晶 種の推算結果は実測した主結晶種と合致した。また，結晶 化温度については，対象モールドフラックス全体で実測 值と推算值の差の絶対值の平均が約 $50^{\circ} \mathrm{C}$ と大きかったが,

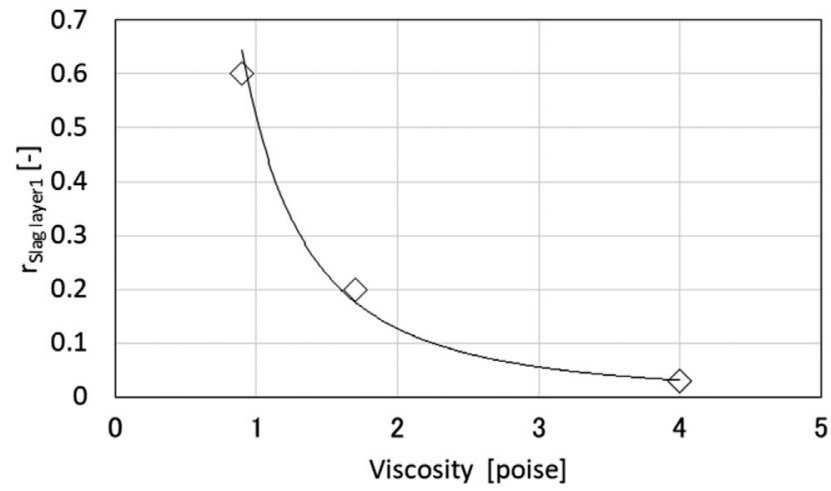

(a)

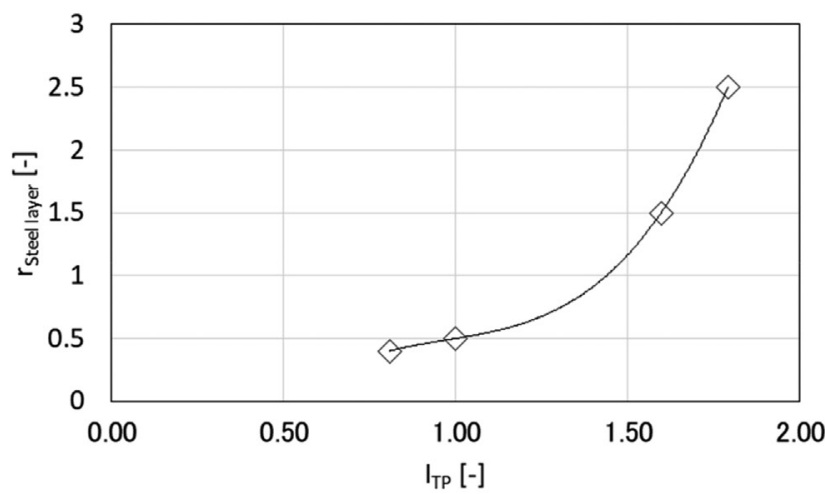

(b)

Fig. 4. (a) Relationship between viscosity of mold flux and $\mathrm{r}_{\text {Slag layer1 }}$ and (b) Relationship between $\mathrm{I}_{\mathrm{TP}}$ and $\mathrm{r}_{\text {Steel layer }}$.

Table 5. Comparison of main crystal estimated by FactSage to measured main crystal.

\begin{tabular}{c|c|c|c|c}
\hline & $\begin{array}{c}\text { Composition } \\
{[\text { mass\%] }}\end{array}$ & $\begin{array}{c}\mathrm{T} . \mathrm{CaO} / \mathrm{SiO}_{2} \\
{[-]}\end{array}$ & $\begin{array}{c}\text { Measured } \\
\text { main crystal }\end{array}$ & $\begin{array}{c}\text { Main crystal } \\
\text { calculated } \\
\text { by FactSage }\end{array}$ \\
\cline { 2 - 5 } & $\mathrm{Al}_{2} \mathrm{O}_{3}$ & 1.2 & Cuspidine & Cuspidine \\
\hline $\mathrm{B}$ & 1.6 & 1.49 & Cuspidine & Cuspidine \\
\hline $\mathrm{B}-10$ & 11.3 & 2.12 & Ghelenite & Ghelenite \\
\hline $\mathrm{B}-20$ & 20.7 & 3.45 & Ghelenite & Ghelenite \\
\hline $\mathrm{B}-30$ & 29.5 & 1.4 & Cuspidine & Cuspidine \\
\hline $\mathrm{C}$ & 1.6 & 1.78 & Cuspidine & Cuspidine \\
\hline $\mathrm{C}-10$ & 11.3 & 2.72 & Mayenite & Mayenite \\
\hline $\mathrm{C}-20$ & 20.7 & 3.54 & Mayenite & Mayenite \\
\hline $\mathrm{C}-25$ & 25.1 & 5.13 & Mayenite & Mayenite \\
\hline $\mathrm{C}-30$ & 29.5 & 5
\end{tabular}



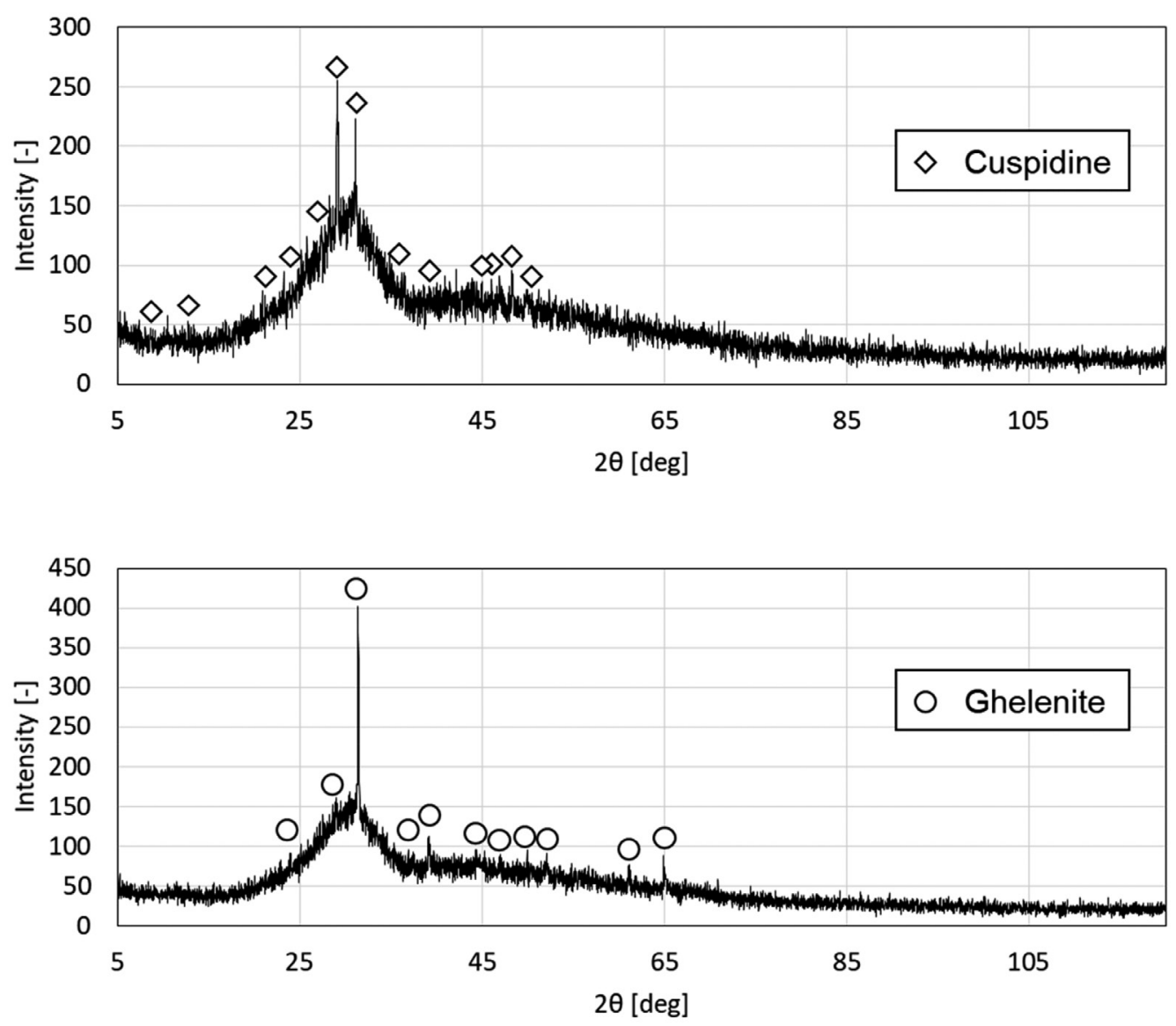

Fig. 5. XRD pattern of B(upper) and B-20(lower).
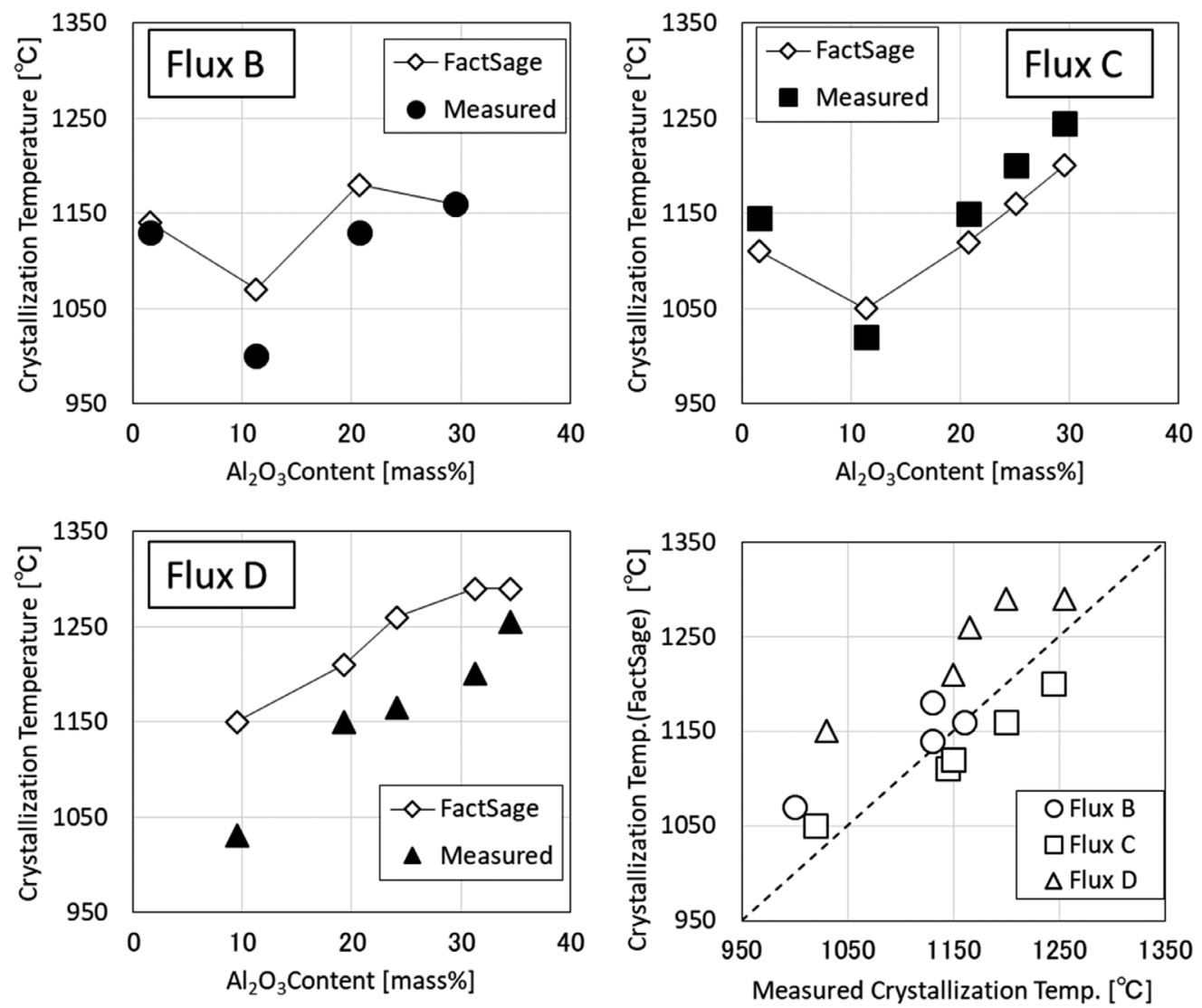

Fig. 6. Comparison of crystallization temperature estimated by FactSage to measured crystallization temperature. 
$\mathrm{Al}_{2} \mathrm{O}_{3}$ 濃度の変化に対する結晶化温度の傾向は全てのモー ルドフラックスにおいて実測值と概ね一致した。

FactSage を用いた粘度の推算結果を Fig.7 に示す。グラフ から分かるように, $\mathrm{Al}_{2} \mathrm{O}_{3}$ 濃度の変化に対する粘度の傾向 が実測值と合致しなかった。特に, $\mathrm{Al}_{2} \mathrm{O}_{3}$ 濃度が 25 mass $\%$ 以上の領域で実測值と FactSageの推算值の乘離が大きい。 この理由は $\mathrm{Al}_{2} \mathrm{O}_{3}$ 濃度が高く塩基度が高い領域での両性酸 化物 $\mathrm{Al}_{2} \mathrm{O}_{3}$ の塩基度への寄与が FactSage では十分再現でき ていないことにあると考えられる。

\section{4. 考察}

\section{4 ・1 モールドフラックス特性, 鋳造条件とモデルパラメータの 関係}

Fig.4に示したように，モールドフラックスの初期組成の 粘度と $\mathrm{r}_{\text {Slag layer } 1}$ の間およびスループット指数 $\mathrm{I}_{\mathrm{TP}}$ と $\mathrm{r}_{\text {Steel layer }}$ の 間には相関があった。それぞれについて考察を行なった。

まず，モールドフラックスの初期組成の粘度とslag layer1の厚みの関係について考察する。これは，モールド フラックス内の $\mathrm{Al}_{2} \mathrm{O}_{3}$ の物質移動に関係していると考えら れる。スループット指数 $\mathrm{I}_{\mathrm{TP}}$ の差が小さいCase1,Case2 を例 に，モールドフラックスの初期組成の粘度の Slag layer1の
厚みに対する影響の推定メカニズムを Fig.8 に示す。Flux B はFlux Aに比べて初期組成の粘度が低く，熱対流や擋拌の 影響を受けやすいことから, 溶融モールドフラックス内の $\mathrm{Al}_{2} \mathrm{O}_{3}$ の物質移動が定性的に速い。そのため, $\mathrm{Al}_{2} \mathrm{O}_{3}$ はモー ルドフラックス中でより上方へ移動しやすく, 溶鋼 - モー ルドフラックス界面付近の $\mathrm{Al}_{2} \mathrm{O}_{3}$ 濃度が低下する。その結 果, 溶鋼 - モールドフラックス界面での酸化還元反応 (反 応 (1) ) が促進され, モールドフラックス中の $\mathrm{Al}_{2} \mathrm{O}_{3}$ 濃度が 上昇することになる。今回のモデルでは, $\mathrm{Al}_{2} \mathrm{O}_{3}$ がより上 方に移動することが，溶鋼 - モールドフラックス界面に隣 接する Slag layer1の厚みが大きいことに相当するため, 初 期組成の粘度の低いFlux Bを用いている Case2の方が Slag layer1の厚みが大きいと考えられる。

次に，スループット指数 $\mathrm{I}_{\mathrm{TP}}$ と Steel layerの厚みの関係に ついて考察する。これは，溶鋼の更新率が関係していると 考えられる。スループット指数 $\mathrm{I}_{\mathrm{TP}}$ の Steel layerの厚みに対 する影響の推定メカニズムを Fig.9に示す。スループット 指数 $\mathrm{I}_{\mathrm{TP}}$ が大きいことは，溶鋼の更新率が高いことを意味し ており，単位時間当たりにモールドフラックスと反応する 溶鋼量も多くなるため, 本モデル上では, Steel layerの厚み が大きいことに相当する。よって，スループット指数 $\mathrm{I}_{\mathrm{TP}}$ が 大きい鋳造条件では, Steel layerの厚みが大きくなると考
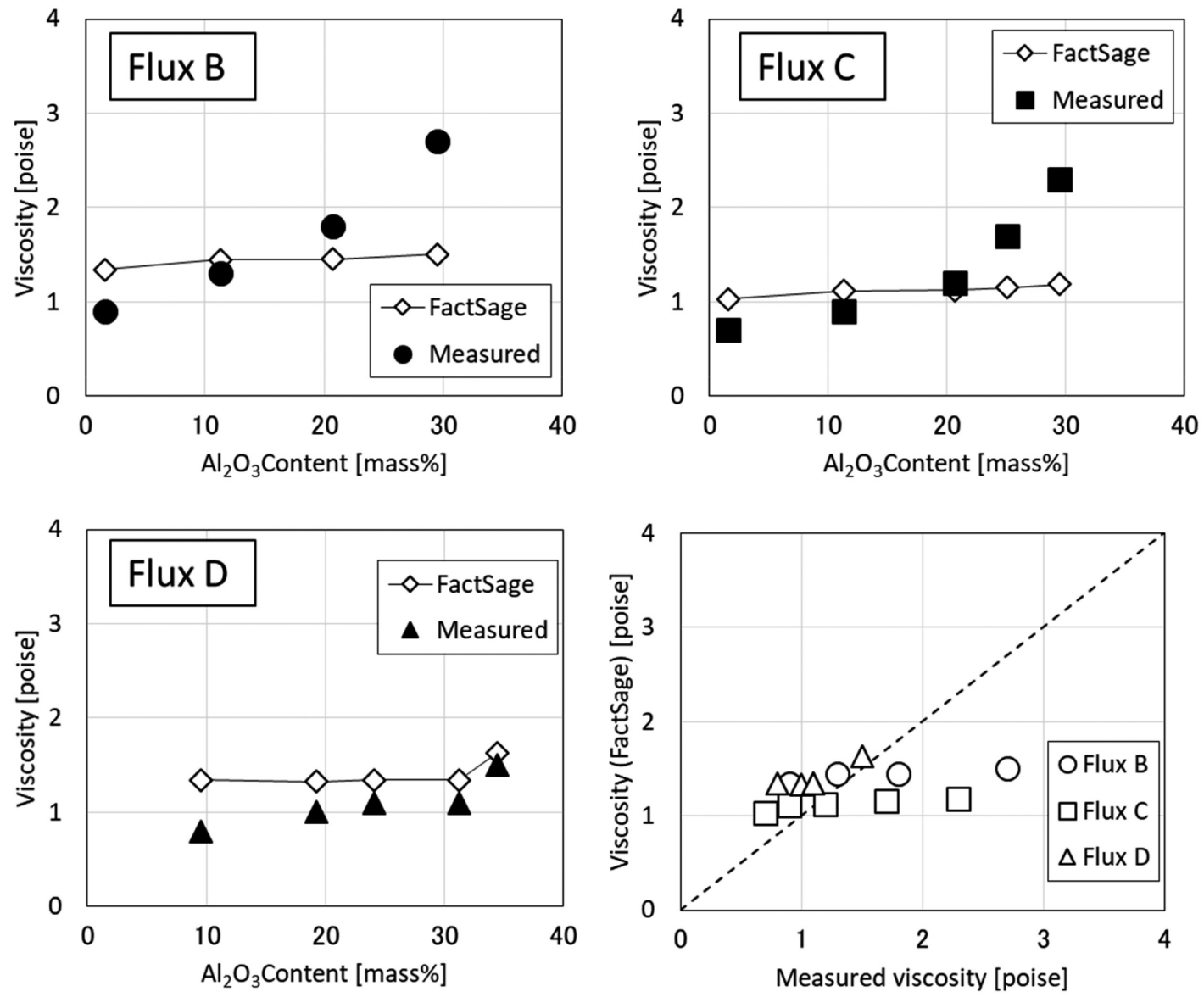

Fig. 7. Comparison of viscosity estimated by FactSage to measured viscosity. 


\section{えられる。}

以上の考察より, モデルパラメータの Slag layer1 とモー ルドフラックスの初期組成の粘度, Steel layerとスルー プット指数 $\mathrm{I}_{\mathrm{TP}}$ には相関があり, モールドフラックスの初期 組成の粘度とスループット (溶鋼流量) がモールドフラッ クス中の $\mathrm{Al}_{2} \mathrm{O}_{3}$ 濃度増加速度に大きく影響を及ぼている と考えられる。また, Fig.4の関係を用いて, 鋳造条件およ びモールドフラックスの特性からこれらのモデルパラメー タを決定できる可能性があると考えられる。

\section{$4 \cdot 2$ 粘度推算式の適用}

Fig.7に示したようにFactSageを用いた粘度の推算值は $\mathrm{Al}_{2} \mathrm{O}_{3}$ 濃度の変化に対する粘度の傾向が実測值と合致しな かった。そこで, 過去に提案されている粘度推算式を適用 し，実測值の傾向を再現できるか検証した。

溶融酸化物の粘度推算式は種々提案されており, 数多く 存在している ${ }^{21-30)}$ 。しかし，導出に用いた組成領域内での 使用に限られ，その組成領域外では精度が大幅に低下す る。これらの粘度推算式の評価を行なったのが, ROUND ROBINプロジェクト (1997-2000年) である ${ }^{31)}$ この報告
書では, 鋼の連続鋳造用モールドフラックスに対する推算 精度が高いのは，修正 Iidaの式 ${ }^{30)}$, Ribouldの式 ${ }^{23)}$ であると 報告されている。その中でも修正 Iidaの式が最も精度が高 く, さらに, 組成や塩基度による両性酸化物の挙動の変化 を考慮できるため, 今回のような広い $\mathrm{Al}_{2} \mathrm{O}_{3}$ 濃度範囲での 粘度推算に適している。修正 Iidaの式は式 (5)〜 (10) で表 される。

$$
\begin{aligned}
& \mu_{\text {calc }}=A \mu_{0} \exp \left(\frac{E}{B i^{(j)}}\right) \\
& \mu_{0}=\sum \mu_{0 i} X_{i} \\
& B i=\frac{\sum\left(\alpha_{i} W_{i}\right)_{B}+\sum\left(\alpha_{i} W_{i}\right)_{A m 2}}{\sum\left(\alpha_{i} W_{i}\right)_{A}+\sum\left(\alpha_{i} W_{i}\right)_{A m 1}} \\
& B i^{(j)}=\frac{\sum\left(\alpha_{i} W_{i}\right)_{B}+\sum\left(\alpha_{i}^{*} W_{i}\right)_{A m 2}}{\sum\left(\alpha_{i} W_{i}\right)_{A}+\sum\left(\alpha_{i}^{*} W_{i}\right)_{A m 1}} \\
& A=1.029-2.078 \times 10^{-3} \mathrm{~T}+1.050 \times 10^{-6} \mathrm{~T}^{2}
\end{aligned}
$$

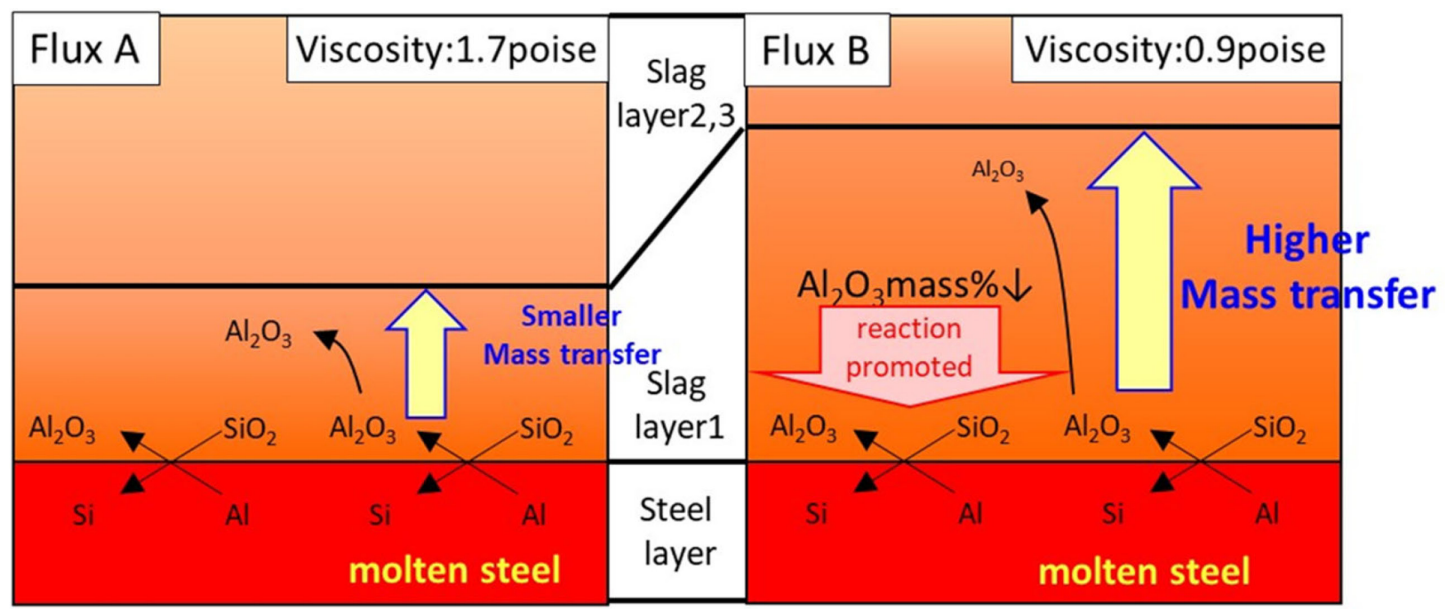

Fig. 8. Effect of viscosity on thickness of slag layer1. (Online version in color.)

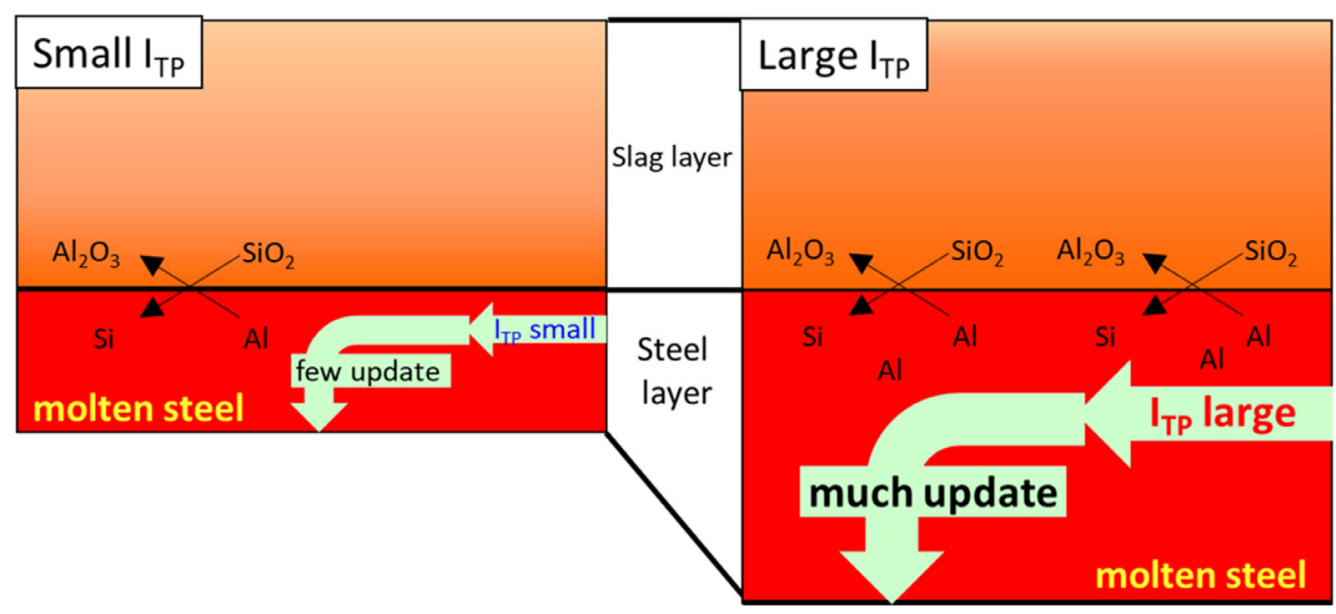

Fig. 9. Effect of ITP on thickness of Steel layer. (Online version in color.) 


$$
E=28.46-2.0884 \times 10^{-2} T+4.000 \times 10^{-6} T^{2}
$$

$\mu_{\text {calc }}[\mathrm{Pa} \cdot \mathrm{sec}]$ :推算粘度, A, E [-] : 定数, $\mu_{0}[\mathrm{~Pa} \cdot \mathrm{sec}]$ :仮 想単分子融体の粘度, $\mu_{0 \mathrm{i}}[\mathrm{Pa} \cdot \mathrm{sec}]$ : 各酸化物成分の仮想融 体の粘度, $\mathrm{Bi}[-]$ : 塩基度指標, $\alpha_{\mathrm{i}}[-]$ : 各酸化物の固有係数, $\mathrm{W}_{\mathrm{i}}[\mathrm{mass} \%]$ : 各酸化物の質量パーセント, $\mathrm{Bi}^{\left({ }^{(j)}\right.}[-]$ : 修正し た塩基度指標, $\mathrm{j}$ [-] : 修正した固有係数の個数, $\alpha_{\mathrm{i}}^{*}[-]$ : 修 正した固有係数， $\mathrm{T}[\mathrm{K}]$ : 温度

修正 Iidaの式では, 溶融酸化物の組成と粘度の関係式を 実測データによって補正することができる。具体的には， 両性酸化物の固有係数 $\alpha_{\mathrm{i}}$ を一定值ではなく，両性酸化物の 質量パーセント $\mathrm{W}_{\mathrm{i}}$ と塩基度指標 $\mathrm{Bi}$ の関数 $\alpha_{\mathrm{i}}^{*}$ とおいて，推 算粘度 $\mu_{\text {calc }}$ と実測粘度の誤差が最小となるようにフィッ ティングする。

Iida は $\mathrm{Al}_{2} \mathrm{O}_{3}$ 濃度が 12 mass $\%$ 以下の濃度範囲の粘度測定 データを基に，連続鋳造用モールドフラックス向けの $\alpha^{*}$ $\mathrm{Al}_{2} \mathrm{O}_{3}$ を 1 次関数として提案している ${ }^{30)}$ 。今回はさらに高 い $\mathrm{Al}_{2} \mathrm{O}_{3}$ 濃度範囲まで精度よく推算する必要があるため, $\alpha_{\mathrm{Al}_{2} \mathrm{O}_{3}}$ の関数形も含めて検討を行なった。補正のための粘 度測定データはTable 3 のデータを用いた。 $\mu_{0 i}, \alpha_{\mathrm{i}}$ は文献值 を用いた ${ }^{30)}$ 。検討の結果, $\mathrm{Al}_{2} \mathrm{O}_{3}$ の固有係数 $\alpha_{\mathrm{Al}_{2} \mathrm{O}_{3}}$ が以下の

$\mathrm{W}_{\mathrm{i}}$ と $\mathrm{Bi}$ の3 次関数 $($ 式 (11)) として得られた。

$$
\begin{aligned}
& \alpha_{\mathrm{Al}_{2} \mathrm{O}_{3}}^{*}=1.37 \mathrm{Bi}-2.27 \times 10^{-1} \mathrm{Bi}^{2} \\
& +1.15 \times 10^{-2} \mathrm{Bi}^{3}-4.07 \times 10^{-1} W_{\mathrm{Al}_{2} \mathrm{O}_{3}} \\
& +1.84 \times 10^{-2} \mathrm{~W}_{\mathrm{Al}_{2} \mathrm{O}_{3}}^{2}-2.6 \times 10^{-4} \mathrm{~W}_{\mathrm{Al}_{2} \mathrm{O}_{3}}^{3}+1.98
\end{aligned}
$$

式（11）を用いた修正Iidaの式の推算結果を Fig.10に示 す。グラフから分かるように, 修正 Iidaの式による推算值 は, FactSageによる推算值とは異なり, $\mathrm{Al}_{2} \mathrm{O}_{3}$ 濃度変化に対 する粘度の傾向を再現することができている。これは，塩 基度, $\mathrm{Al}_{2} \mathrm{O}_{3}$ 濃度によって変化する $\mathrm{Al}_{2} \mathrm{O}_{3}$ の固有係数の傾向 を再現できているからだと考えられる。よって, 式 (11) を 用いることで, $\mathrm{Al}_{2} \mathrm{O}_{3}$ 濃度が大きく変化する高 $\mathrm{Al}$ 含有鋼鋳 造中のモールドフラックスの粘度を精度よく推算できる。

\section{5. 結言}

高合金鋼における安定鋳造を目的に, 高 $\mathrm{Al}$ 含有鋼鋳造中 のモールドフラックスの組成変動と, それに伴う特性変動 を予測する手法を検討し，以下の知見が得られた。

(1) 0.7 mass\% $\%$ 鋼および通常 $\mathrm{Al}$ キルド鋼に対し, $\mathrm{Al}_{2} \mathrm{O}_{3}$ 濃 度 $(1.3 \sim 6.0$ mass $\%)$, 塩基度の異なる 3 種類のモール ドフラックスを適用した。鋳造中に鋼中 [Al $]$ にっ
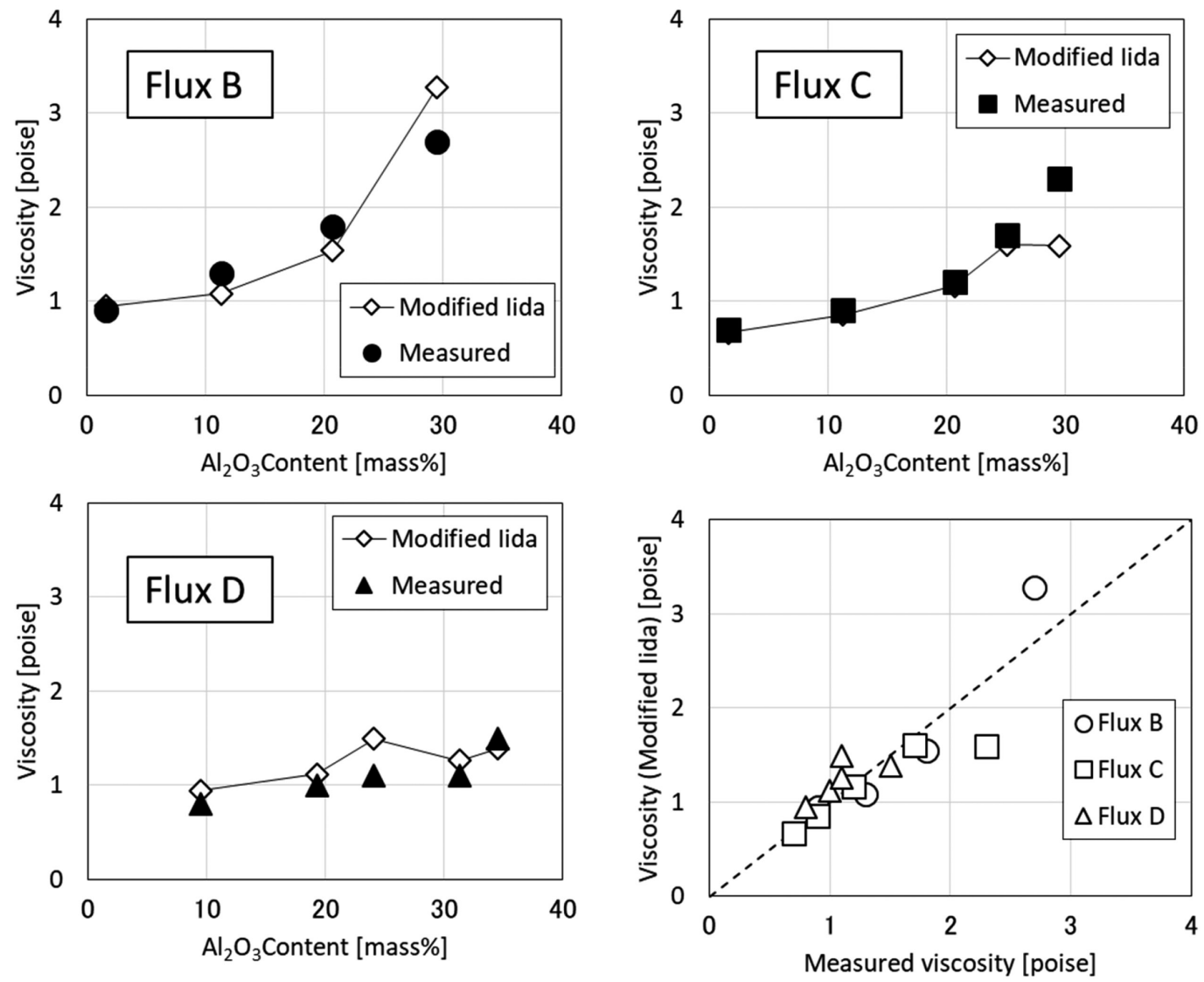

Fig. 10. Comparison of viscosity estimated by Modified Iida's formula to measured viscosity. 
てモールドフラックス中の酸化物が還元されること で, $\mathrm{Al}_{2} \mathrm{O}_{3}$ 濃度が最大約 30 mass\%まで上昇した。鋳造 中の成分変化を組成変動モデル (Equilibrium Effective Reaction Zone Model）によって再現した。

(2) 得られたモデルパラメータ (Slag layer, Steel Layer厚 み等）と，鋳造条件，モールドフラックスの物性との 関係を考察した結果，モールドフラックスの粘度と スループット（溶鋼流量）がモールドフラックス中の $\mathrm{Al}_{2} \mathrm{O}_{3}$ 濃度増加速度に大きく影響を及ぼす。

(3) 熱力学ソフト FactSageを用いて主結晶および結晶化温 度を推算した結果, 主結晶種は推算結果と実測結果で 合致し, 結晶化温度の推算值と実測值の誤差は約 $50^{\circ} \mathrm{C}$ であった。また, モールドフラックス中の $\mathrm{Al}_{2} \mathrm{O}_{3}$ 濃度変 化に対する主結晶および結晶化温度の変化を推算でき た。

（4）FactSageを用いて粘度を推算した結果，モールドフ ラックス中の $\mathrm{Al}_{2} \mathrm{O}_{3}$ 濃度変化に対する粘度の変化は推 算できなかった。一方, 組成による両性酸化物の塩基 性挙動変化を考慮した修正 Iidaの式を, $\mathrm{Al}_{2} \mathrm{O}_{3}$ 濃度が 1.6 mass\%〜 34.5 mass\%のモールドフラックスの粘度 測定データを用いて補正した結果，モールドフラック ス中の $\mathrm{Al}_{2} \mathrm{O}_{3}$ 濃度変化に対する粘度変化を推算できた。

\section{文献}

1 ) K.C.Mills and A.B.Fox: ISIJ Int., 43(2003), 1479. https://doi.org/ 10.2355/isijinternational.43.1479

2 ) K.C.Mills: ISIJ Int., 56(2016), 1. https://doi.org/10.2355/isijinternational. ISIJINT-2015-231

3 ) K.C.Mills: ISIJ Int., 56(2016), 14. https://doi.org/10.2355/isijinternational. ISIJINT-2015-355

4 ) T.Miyake, J.Yoshida and T.Mimura: Proc. 13th China-Japan Symp. on Science Technology of Iron and Steel, The Chinese Society for Metals, Beijing, (2013), 171.

5 ) J.Rudnizki, R.Shepherd, E.Balichev, S.Karrasch and F.Kruger: Proc. 8th European Continuous Casting Conf. (ECCC), ASMET, Leoben, (2014), 1013.

6 ) W.Wang, B.Lu and D.Xiao: Metall. Mater. Trans. B, 47(2016), 384. https://doi.org/10.1007/s11663-015-0474-z

7 ) J.-W.Cho, S.Yoo, M.-S.Park, J.-K.Park and K.-H.Moon: Metall. Mater. Trans. B, 48(2017), 187. https://doi.org/10.1007/s11663-0160818-3

8 ) M.-S.Kim, M.-S.Park, S.-E.Kang, J.-K.Park and Y.-B.Kang: ISIJ Int., 58(2018), 686. https://doi.org/10.2355/isijinternational.ISIJINT2017-603
9 ) S.He, Z.Li, Z.Chen, T.Wu and Q.Wang: Steel Res. Int., 90(2019), 1800424. https://doi.org/10.1002/srin.201800424

10) K.Watanabe, H.Takahashi, A.Kiyose and K.Miyazawa: CAMP-ISIJ, 8(1995), 160 (in Japanese).

11) A.Kiyose, H.Goto, K.Miyazawa, K.Watanabe, H.Takahashi and W.Yamada: CAMP-ISIJ, 8(1995), 161 (in Japanese).

12) H.Nishikawa, I.Kimura, H.Bada, S.Moriwaki, N.Otani and F.Sudo: Tetsu-to-Hagané, 70(1984), S927 (in Japanese). https://doi. org/10.2355/tetsutohagane1955.70.12_S923

13) T.Kishi, H.Tsuboi, H.Takeuchi, T.Nakano, M.Yamamiya and T.Ando: Seitetsu Kenkyu, 324(1987), 10 (in Japanese).

14) Q.Wang, S.Qiu and P.Zhao: Metall. Mater. Trans. B, 43(2012), 424. https://doi.org/10.1007/s11663-011-9600-8

15) Y.-B.Kang, M.-S.Kim, S.-W.Lee, J.-W.Cho, M.-S.Park and H.-G. Lee: Metall. Mater. Trans. B, 44(2013), 309. https://doi.org/10.1007/ s11663-012-9769-5

16) M.-S.Kim and Y.-B Kang: Calphad, 61(2018), 105. https://doi.org/ 10.1016/j.Calphad.2018.02.010

17) M.-A.van Ende and I.-H.Jung: ISIJ Int., 54(2014), 489. https://doi. org/10.2355/isijinternational.54.489

18) Y.-s.Hsieh, Y.Watanabe, S.Asai and I.Muchi: Tetsu-to-Hagané, 69(1983), 596 (in Japanese). https://doi.org/10.2355/tetsutohagane1955. 69.6_596

19) R.Ding, B.Blanpain, P.T.Jones and P.Wollants: Metall. Mater. Trans. B, 31(2000), 197. https://doi.org/10.1007/s11663-000-0145-5

20) M.-A.van Ende, Y.-M.Kim, M.-K.Cho, J.Choi and I.-H.Jung: Metall. Mater. Trans. B, 42(2011), 477. https://doi.org/10.1007/s11663-0119495-4

21) K.Nakajima, H.Mizukami, M.Kawamoto and Z.-i.Morita: Tetsuto-Hagané, 80(1994), 509 (in Japanese). https://doi.org/10.2355/ tetsutohagane1955.80.7_509

22) M.Kosaka and S.Minowa: Tetsu-to-Hagané, 52(1966), 1039 (in Japanese). https://doi.org/10.2355/tetsutohagane1955.52.7 1039

23) P.V.Riboud, Y.Roux, L.-D.Lucas and H.Gaye: Fachber. Hüttenprax. Metallweiterverarb., 19(1981), 859 (in German).

24) M.D.Lanyi and C.J.Rosa: Ironmaking Steelmaking, 9(1982), 25.

25) K.Koyama, Y.Nagano and T.Nakano: Seitetsu Kenkyu, 324(1987), 39 (in Japanese).

26) M.Hanao, M.Kawamoto, T.Tanaka and M.Nakamoto: ISIJ Int., 46(2006), 346. https://doi.org/10.2355/isijinternational.46.346

27) E.Benavidez, L.Santini, M.Valentini and E.Brandaleze: Procedia Mater. Sci., 1(2012), 389. https://doi.org/10.1016/j.mspro.2012.06.052

28) X.Qi, G.-h.Wen and P.Tang: J. Iron Steel Res. Int., 17(2010), 6. https://doi.org/10.1016/S1006-706X(10)60105-7

29) Z.Zhang, G.Wen, P.Tang and S.Sridhar: ISIJ Int., 48(2008), 739. https://doi.org/10.2355/isijinternational.48.739

30) T.Iida: Estimation of Viscosities of Slags and Glasses, AGNE Gijutsu Center, Tokyo, (2003) (in Japanese).

31) K.C.Mills, L.Chapman, A.B.Fox and S.Sridhar: Scand. J. Metall., 30(2001), 396. https://doi.org/10.1034/j.1600-0692.2001.300608.x 